\section{Science sans frontières}

\author{
Will the European
}

Union's member states

ever put the goal of

continental cohesion in

science ahead of their

individual national

interests? Quirin

Schiermeier considers the prospects for

creating a 'European

Research Area'.

$\mathrm{T}$ he road towards European integration is littered with false starts and missed deadlines. In 1970, a panel chaired by the prime minister of Luxembourg, Pierre Werner, proposed full monetary union among the members of the European Economic Community - as it was then called - by 1980 . Yet more than three decades after his report, several European Union (EU) nations, including Britain, have yet to decide whether they want to adopt the euro, the EU's nascent single currency.

It is a similar story in science. In 1973, Germany's Ralf Dahrendorf, then European Commissioner for research, suggested the creation of a European scientific area, within which member governments would coordinate their national research policies. The proposal languished. In fact, when Philippe Busquin, the Belgian former physicist who now occupies the post once filled by Dahrendorf, last year launched his 'big idea', dubbed the European Research Area (ERA), there were few in Brussels with a sufficiently long memory to comment on its similarity to Dahrendorf's stillborn scheme.

Busquin's proposal, published in January 2000 , noted the importance of scientific excellence to the EU's continued economic competitiveness. Today, Europe produces around one-third of the world's scientific knowledge. Butby many measures of scientific output and productivity, Europe performs poorly compared with North America and Japan, and when it comes to spending on research, the gap is widening (see table, opposite).

Among other things, Busquin blamed fragmentation of resources and infrastruc-

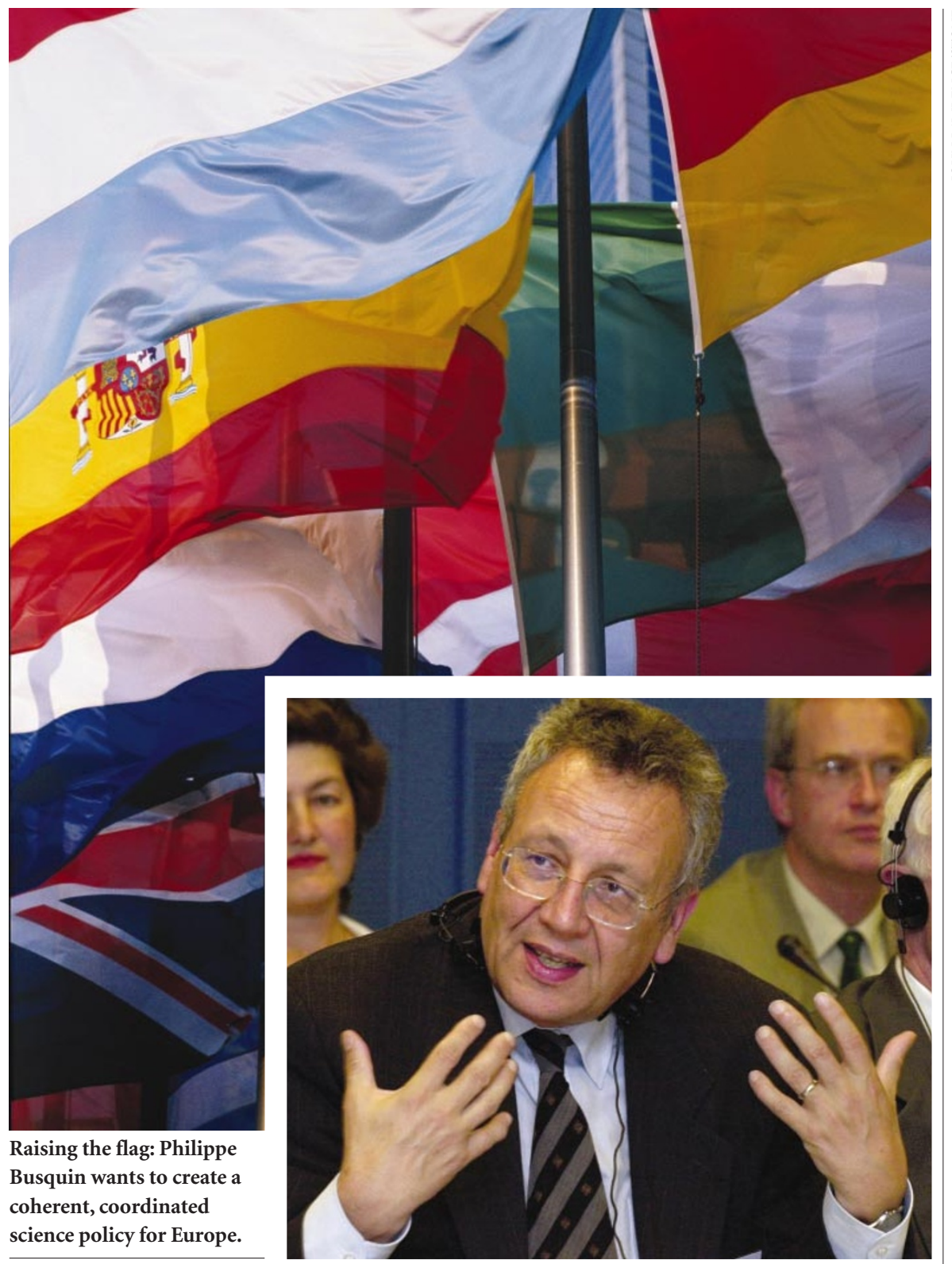

ture, a lack of intergovernmental coordination, and obstacles to mobility of researchers - the downside, perhaps, of the cultural and linguistic diversity across the EU's 15 member states. His document lamented the lack of a pan-European vision: "It cannot be said that there is today a European policy on research. National research policies and the Union policy overlap without forming a coherent whole."

\section{Far-reaching ambitions}

The ERA aims to create the desired cohesion. Its goals include the harmonization of patent law, support for large-scale infrastructure projects and existing centres of excellence, and the creation of new, 'virtual' centres using networking technology. It aims to integrate scientists from the central and eastern European nations that are currently queueing up to join the EU, while strengthening scientific links between the EU and the rest of the world. It also stresses the importance of commissioning research to address important policy decisions that face the EU. Most importantly, Busquin aims to create a common European 'market' for science, technology and higher education, similar to that which already exists for goods and services, by boosting the pan-European mobility of researchers at all career stages, and by improving coordination between national research-funding programmes.

Darhendorf's proposal similarly stressed the need to coordinate national research programmes. But whereas his idea soon disappeared from view, Busquin's ERA proposal has entered the vocabulary of Europe's leaders, who adopted it at the Lisbon EU summit in March last year. The ERA has become a political priority, according to the public statements of national governments. "The ERA comes at the right time and has our full backing," David Sainsbury, Britain's science minister, told a meeting of scientists and policy-makers held in Brussels last month to 
discuss the ERA's implementation.

But as the travails of monetary union reveal, even Europe's highest priorities can fall foul of inertia and conflicting national interests. Twenty months on from Busquin's original proposal, it seems that the obstacles that stand in the way of a true pan-European science policy are bigger than had been thought. One problem is that there are no policy instruments to force national research agencies to collaborate. The original thinking behind the Common Agricultural Policy (CAP) may be largely discredited, but those who are familiar with the workings of the EU argue that its success in coordinating national farming policies cannot be doubted. The ERA, they note, lacks such a powerful legal mechanism.

Given that a scientific equivalent of the CAP is not on the EU's agenda, the fate of Busquin's ERA lies in the willingness of national officials and representatives of panEuropean research organizations to turn their enthusiastic statements into action. However, doubts are beginning to emerge. "There seems to be an absence of political will," says Enric Banda, secretary-general of the Strasbourgbased European Science Foundation (ESF).

Meanwhile, the European Commission more specifically, its five-year, rolling Framework programmes for research — remains the driving force. The sixth Framework, due to start in 2003, is intended to ignite the touchpaper on the ERA. The 17.5-billion-euro (US\$15.9-billion) programme is currently being discussed by the European parliament, and will also be on the agenda of next week's meeting of the EU council of research ministers from the member states in Luxembourg. Both bodies will have a say on its final form.

\section{Economics of scale}

The sixth Framework proposal turns its back on the proliferation of smaller, collaborative projects that have characterized its predecessors, giving priority to large-scale projects and research infrastructure (see Nature 410, 4; 2001). Large-scale projects are divided into 'Networks of Excellence' long-term multidisciplinary projects in fundamental science - and 'Integrated Projects' - efforts on a similar scale in applied and industrial $\mathrm{R} \& \mathrm{D}$. The proposal also gives participants more autonomy in managing individual projects, and aims to integrate scientists from the 11 candidate member countries of central and eastern Europe.

To Busquin's chagrin, however, the proposal has been attacked on several fronts. Many scientists fear that the new rules will see funding divided among already wealthy research groups. "There will be no 'equal and unbiased access' to EU funding, as claimed," argues Martin Grabert, head of the Brusselsbased liaison office of Germany's science organizations. "The scheme is tailor-made for 'old-boy networks' with plenty of experience and resources.” In Poland, Slovenia and

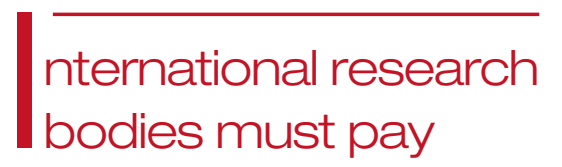
more than lip-service to the goal of coordinating
their activities.

several other candidate EU member states, these worries are particularly acute. Scientists in these countries fear that they could be excluded, rather than integrated, by the proposal (see Nature 411, 512; 2001).

\section{Precision planning?}

The sixth Framework proposal has also been criticized for its vagueness. Although it identifies a series of 'priority areas', defining general scientific themes, the details of each will not be filled in until the European Commission has called for 'expression of interest' early next year. In response to previous complaints from the scientific community, the commission has decided this time not to define the precise scope of each component of the Framework programme until it has gained some input on the sort of projects that EU researchers wish to pursue.

Seasoned observers of EU research policy have some sympathy with Busquin's predicament - in attempting to consult with scientists, he has come under attack from the European Parliament and the member states. For example, Gerard Caudron, the French socialist member of the European Parliament who is coordinating its response to the Framework proposal, has suggested that the priority area that covers climate and other enviromental research, dubbed 'sustainable development and planet changes', should be completely rewritten, while others must be "fleshed out and better structured".

Although the unrest that surrounds the sixth Framework does not augur well for the ERA, Busquin has always stressed that his vision could never be realized through the Framework system alone. Indeed, the current Framework accounts for only 5.4\% of total public spending on R\&D across the EU. For the ERA to become reality, national governments must address the problems that currently restrict free movement of researchers across national borders, and the various national and international research bodies must pay more than lip-service to the goal of coordinating their activities.

Busquin has made removing obstacles to mobility a high priority. He wants a scientist to be able to relocate from, say, London to Milan with the same ease that an American researcher might move from New York to San Francisco. "I would like researchers in Europe to be free and ready to go wherever an envisaged project has the best chance of realization," says Busquin. The European Commission has been trying to foster greater mobility through the Framework programme for years. The proposed budget for the sixth Framework, for instance, contains 1.8 billion euros for 'human resources' projects, including grants for training courses and postdoctoral fellowships.

But such activities barely scratch the surface of the changes desired under the ERA. To move things along, the European Commission has devised a mobility strategy, which was published in June. This details a range of reforms, including the harmonization of social-security rights and mutual recognition of degrees and diplomas. It also encourages the creation of 'mobility centres' - local offices that will deal with legal and administrative problems - and a network of national ombudsmen, who will handle practical complaints from guest researchers.

\section{Obstacle course}

But all of this will have to be enacted and paid for by the EU's member nations. For several months, Busquin has been campaigning hard to prepare the ground, taking his case personally to senior officials in the member states and trying to convince them of the need to set up inter-ministerial meetings to solve the problems that currently restrict most European scientists to their country of birth.

Although there are few reliable statistics, it is clear that the obstacles to mobility are many. Moving from one country to another can leave researchers out of pocket. In the absence of bilateral or European social-security agreements, for instance, visiting scientists may be forced to pay for social benefits they cannot enjoy, lose pension rights, or risk double taxation (see Nature 407, 427-429; 2000). In the case of researchers travelling on grants paid in euros to countries such as Britain and Sweden, which do not yet use the single currency,

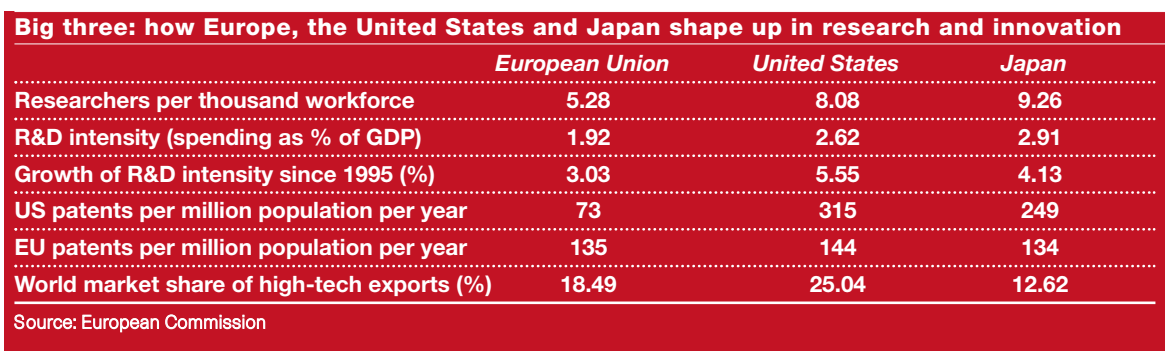



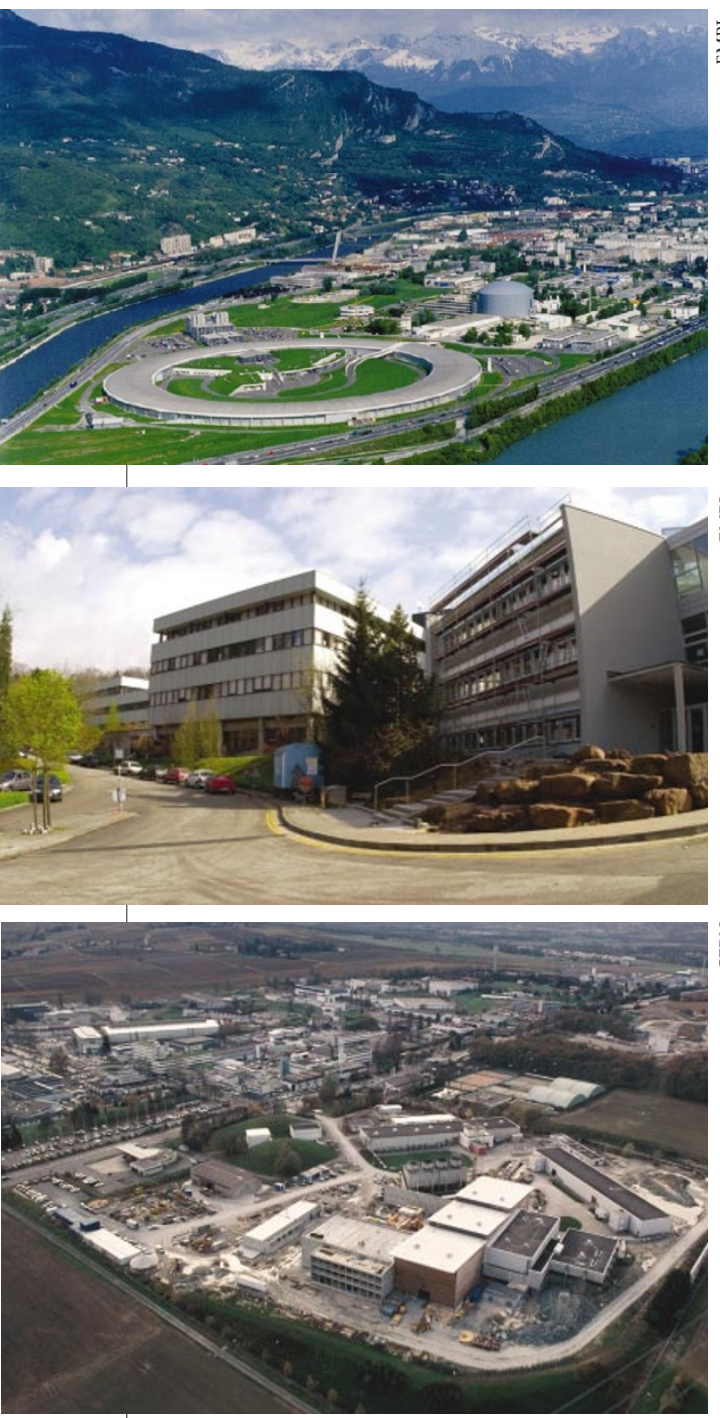

Success stories: is there scope for more projects modelled on the European Synchrotron

Radiation Facility (top), the European Molecular Biology Laboratory (middle) and CERN (above)?

fluctuations in the euro's value can also cause problems (see Nature 406, 551;2000).

Even high-profile EU-funded projects can suffer. The Centre for Advanced Manufacturing Technologies at the Technical University of Wroclaw in Poland, for instance, last year received a grant of 1.1 million euros, of which 300,000 euros were earmarked for fixed-term employment of scientists from elsewhere in Europe. An ideal candidate, who was enthusiastic to move, was soon found at the Technical University of Dresden in Germany. But Knut Grossmann, a mechanical engineer, is still in Dresden - the two universities were unable to find a proper contractual arrangement for his guest stay. A request for advice, which the Wroclaw centre sent to the European Commission in Brussels, has so far remained unanswered.

There are also concerns - particularly acute in southern Europe - that scientists who spend time away from their home country will find themselves at the back of the employment queue on their return. "Whoever moves loses his seat," observes Ramon Marimon, Spanish secretary of state for science and technology policy, quoting a traditional Spanish proverb.

Some countries have made moves to improve the situation. Belgium, for instance, earlier this year approved a 2.5-million-euro programme designed to facilitate the involvement of Belgian scientists in EU programmes, which will include measures to encourage the mobility of researchers. But other changes on a national level threaten further restrictions. For instance, proposed regulations on the maximum time allowed between graduation and assistant professorship in Germany (see Correspondence, page 773) could restrict the ability of its young scientists to change labs or go abroad during their postdoctoral period.

European Commission officials have no illusions about the difficulty of the task ahead. "It will take a regular dialogue between the commission, national governments, regions, communities and universities to progressively remove the various obstacles," says Elisabeth Colinet, head of a unit that is charged with implementing the ERA. "However, when it comes to legislative and administrative changes, the member states have to take the lead.'

\section{Managing or meddling?}

Busquin's goal of coordinating the activities of national research agencies is similarly beset with difficulties. Some observers even claim that this would run counter to one of the EU's fundamental principles - that of 'subsidiarity'. This states that the EU should not carry out activities that can be performed adequately at a regional or national level. But given the complaints about the adequacy of the current set-up detailed in the original ERA proposal, commission officials reject this argument.

Irrespective of arguments about subsidiarity, however, national governments are anxious about the idea that tax money paid by their citizens could be spent abroad. Tony Mayer, the ESF's head of scientific coordination, says that thinking is still dominated by the notion of juste retour, in which participation in EU programmes is proportional to financial contributions. "All states try jealously to get back what they have paid in," he says.

To break free from such limitations, Busquin promotes a flexible approach in which individual research agencies of the member states, with or without the involvement of the European Commission, are encouraged to come together to support projects of mutual interest. In the jargon of the ERA, such projects have 'variable geometry'.

The idea is not a new one. The ESF, for instance, which was created as an association of national research agencies, has coordinated pan-European projects of this nature for many years, linking related activities in different countries. Last year, it went further, launching its EUROCORES programmes, under which participating agencies agree to pool their funding and operate a centralized system for the selection of projects. EUROCORES programmes are each likely to have budgets of several million euros. Peer review of proposals for the first, on anthropology and linguistics, is now under way.

\section{Framework for progress}

Busquin wants to see more of this type of activity. But in the long run, many scientists and policy-makers believe that realizing the ERA may require the creation of an independent European funding agency, fed by funds from national organizations and complementing the EU Framework programme (see Nature 411, 871; 2001).

The ESF is especially keen on the idea of creating a new European research council, along the lines of the US National Science Foundation, and is touting itself as the natural body to take the plan forward. "We are willing to play a role," says the ESF's Banda. He adds that the ESF plans to appoint a highlevel group to carry out an in-depth study of the potential advantages and disadvantages.

The Danish government, which will begin a six-month presidency of the $\mathrm{EU}$ in July, is also enthusiastic about the idea. But bringing a European research council to fruition will take years - and may ultimately fall foul of the subsidiarity principle.

Some scientists argue that the EU should instead concentrate on building from existing successful models of European scientific cooperation - centralized facilities such as the European Synchrotron Radiation Facility in Grenoble, the European Molecular Biology Laboratory in Heidelberg, and CERN, the European particle physics laboratory near Geneva. "If the EU is serious about increasing Europe's competitiveness, it should think about ways of setting up at least five new large facilities, preferably in the fields of genome research and cell and developmental biology," says physiologist Brian Heap of the University of Nottingham, vicepresident of Britain's Royal Society.

Ultimately, however, the fate of the ERA lies in the willingness of EU member states to turn their stated commitment to Busquin's vision into reality. "The ERA's makers will be judged by what they do, not by what they say," says Marimon. "If they really act, the ERA could indeed become one of the main achievements in our century."

Quirin Schiermeier is Nature's German correspondent.

European Research Area proposal

curopa.eu.int/comm/research/area.htm

Sixth Framework proposal

europa.eu.int/comm/research/nfp.htm

European Commission proposal for mobility of researchers

www.cordis.lu/rtd2002/fp-thematic/mobility.htm

European Science Foundation

www.esf.org 